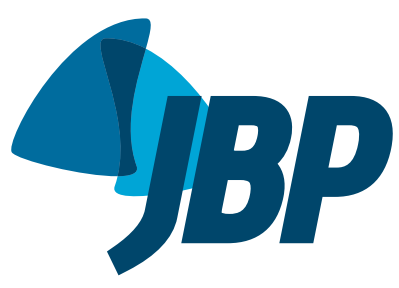

1. Curso de Medicina, Universidade Federal de Alagoas, Campus Arapiraca, Arapiraca (AL) Brasil.

2. Fundação Oswaldo Cruz - Fiocruz Rio de Janeiro (RJ) Brasil.

a. (iD) http://orcid.org/0000-0003-0837-8254

b. (iD http://orcid.org/0000-0002-1183-8920

c. (iD) http://orcid.org/0000-0002-6022-6584

d. (iD http://orcid.org/0000-0003-0823-0866

e. iD http://orcid.org/0000-0002-6595-8274

Submitted: 6 December 2018.

Accepted: 1 February 2019

Study carried out under the auspices of the Curso de Medicina, Universidade

Federal de Alagoas, Campus Arapiraca, Arapiraca (AL) Brasil.

\section{Trends in tuberculosis mortality in Brazil (1990-2015): joinpoint analysis}

\author{
Carlos Dornels Freire de Souza ${ }^{1, a}$, João Paulo Silva de Paiva ${ }^{1, b}$, \\ Leonardo Feitosa da Silva ${ }^{1, c}$, Thiago Cavalcanti Leal ${ }^{1, d}$, \\ Mônica de Avelar Figueiredo Mafra Magalhães²,e
}

\begin{abstract}
The objective of this study was to analyze trends in the tuberculosis mortality rate in Brazil (1990-2015) in an ecological time-series analysis. The indicators were obtained from the Brazilian National Ministry of Health. A joinpoint regression model was applied for the temporal analysis, with a level of significance of $5 \%$. During the period in question, there was a trend toward a reduction in mortality in the country as a whole $(p<0.001)$ and in each of its five regions. The states with the highest tuberculosis mortality rates were Rio de Janeiro (7.0/100,000 population) and Pernambuco (5.0/100,000 population). Eleven states and the Federal District of Brasilia showed downward trends. Only the state of Alagoas showed a significant increase $(p<0.001)$. The temporal behavior observed indicates that tuberculosis continues to be a major public health problem in Brazil.
\end{abstract}

Keywords: Tuberculosis/epidemiology; Tuberculosis/mortality; Mortality/trends; Epidemiologic studies.
Tuberculosis is an infectious disease caused by Mycobacterium tuberculosis. It is estimated that one fourth of the world population is infected with $M$. tuberculosis. ${ }^{(1)}$ In 2017 alone, an estimated 10 million people developed tuberculosis and 1.3 million died from the disease. Currently, tuberculosis is the leading cause of death among infectious diseases worldwide. ${ }^{(2)}$ Also in 2017 , a total of 72,770 new cases of tuberculosis were reported in Brazil, translating to an incidence of 35.0 cases $/ 100,000$ population. Although the Northeast and Southeast accounted for the highest number of cases $(18,884$ and 33,769 , respectively), in terms of disease incidence, the North ranked first ( $46.6 / 100,000$ population), followed by the Southeast (38.8/100,000 population). ${ }^{(3,4)}$

This spatial heterogeneity is even more marked when rates are analyzed state by state. The state of Amazonas had the highest incidence rate in 2017 (74.7/100,000 population), whereas the state of Tocantins had the lowest $(10.0 / 100,000)$. In addition, ten states had a higher incidence rate than the national average in that same year. ${ }^{(4)}$

Concern about the global epidemiological scenario has led to the development of a new global strategy for fighting tuberculosis, known as End TB Strategy. ${ }^{(5)}$ Proposed by the World Health Organization and approved by the World Health Assembly in 2014, this strategy proposes targets of a $90 \%$ reduction in tuberculosis incidence and a $95 \%$ reduction in tuberculosis mortality by $2035 .^{(5)}$

Being one of the countries with the highest incidence of tuberculosis and being in two of the three groups of priority countries-ranking 20th regarding the burden of disease and 19th regarding the tuberculosis/HIV coinfection, Brazil has formulated the "Plano Nacional pelo Fim da Tuberculose como Problema de Saúde Pública" (Brazilian National Plan to End Tuberculosis as a Public Health Problem). (6) This plan is based on three pillars of action: integrated, patient-centered care and prevention; bold policies and supportive systems; and intensified research and innovation. ${ }^{(6)}$

In addition to the commitments made nationally and internationally, the relevance of studies of tuberculosis mortality lies in the fact that tuberculosis is a preventable disease. $(2,5,6)$ Early diagnosis and appropriate treatment are imperative in this regard, because, in countries with universal health care system coverage, the proportion of people who die from tuberculosis may be less than $5 \%$. (2) In this regard, tuberculosis mortality also indicates deficiencies in the health care system. ${ }^{(2,5)}$

In this scenario, the study of mortality rate trends may contribute to the management of the national plan, providing supports for public health decision making, such as identification of the most vulnerable regions and of weaknesses in the disease surveillance system. Therefore, the objective of the present study was to analyze trends in the tuberculosis mortality rate in the Brazilian regions and states for the period 1990-2015.

This was an ecological time-series analysis. Mortality data were extracted from the Brazilian National Ministry of Health Mortality Database, considering codes A15 to A19 of the International Classification of Diseases, 10th revision. The following equation was utilized to calculate the indicator: number of deaths/population for the reference year $\times 100,000$. A joinpoint regression model was applied for the temporal analysis. This model tests

Correspondence to:

Carlos Dornels Freire de Souza. Universidade Federal de Alagoas, Avenida Manoel Severino Barbosa, s/n, Bom Sucesso, CEP 57309-005, Arapiraca, AL, Brasil.

Tel.: 5587 99622-0698. E-mail: carlos.freire@arapiraca.ufal.br

Financial support: None. 
whether a multi-segmented line is statistically better to describe the temporal evolution of a dataset than is a straight or less-segmented line. ${ }^{(7)}$ The model allows us to detect the indicator trend (whether stationary, upward, or downward) and the points where the trend changes, allowing us to calculate the annual percent change (APC) and the percent change over the entire study period, known as average annual percent change. For each trend detected, we used a $95 \% \mathrm{CI}$ and a level of significance of $5 \%$. The analyses were performed with the Joinpoint Regression Program, version 4.5.0.1 (National Cancer Institute, Bethesda, MD, USA).

The tuberculosis mortality rate in Brazil between 1990 and 2015 ranged from $2.2 / 100,000$ population (in 2014) to $3.8 / 100,000$ population (in 1994). The regression model indicated three temporal behaviors: the first one, a stationary behavior between 1990 and 1998 (APC: 0.53 ; $95 \% \mathrm{CI}:-0.3$ to $1.3 ; \mathrm{p}=0.2$ ); the second one, a decreasing behavior between 1998 and 2003 (APC: -5.81 ; $95 \% \mathrm{CI}$ : -8.0 to -3.6 ; $\mathrm{p}<0.001)$; and the third one, also a decreasing behavior (APC: $-1.88 ; 95 \%$ $\mathrm{CI}:-2.3$ to $-1.4 ; \mathrm{p}<0.001)$. Analysis of the entire study period showed a significant downward trend in the mortality rate in Brazil (APC: $-1.9 ; 95 \% \mathrm{CI}$ : -2.4 to -1.4 ; $\mathrm{p}<0.001$ ), which decreased from 3.6 deaths $/ 100,000$ population in 1990 to $2.3 / 100,000$ population in 2015 , translating to a mean rate of $3.0 / 100,000$ population in the period in question (Figure 1 ).

Analysis by macro-region showed that the highest mortality rates were observed in the Southeast (3.5/100,000 population) and Northeast (3.0/100,000 population). In the temporal analysis, all five regions exhibited a statistically significant decreasing behavior, with the Southeast showing the largest percent reduction (APC: $-2.7 ; 95 \% \mathrm{CI}:-3.1$ to $-2.2 ; \mathrm{p}<0.001$ ) and the Northeast showing the smallest percent reduction (APC: -0.5 ; $95 \%$ CI $:-0.9$ to -0.01 ; Figure 1 and Table 1 ).

Analysis by state showed that the highest tuberculosis mortality rates were observed in Rio de Janeiro (7.0/100,000 population) and in Pernambuco (5.0/100,000 population). Analysis of the temporal model showed that 11 states and the Federal District of Brasilia exhibited a downward trend. Of those 11 states, 4 are in the North, 1 is in the Northeast, 3 are in the Southeast, 2 are in the South, and 1 is in the Central-West, as is the Federal District of Brasília. In contrast, 14 states exhibited a stationary pattern, of which 3 are in the North, 7 are in the Northeast, 1 is in the Southeast, 1 is in the South, and 2 are in the Central-West. Only the state of Alagoas exhibited an upward trend (APC: $1.0 ; 95 \% \mathrm{CI}: 0.2-1.8$; p < 0.001; Table 1).

The downward trend observed in the tuberculosis mortality rate in Brazil is consistent with the global temporal pattern. Between 2000 and 2015, tuberculosis mortality worldwide decreased by $29 \%$ in HIV-negative individuals and by $44 \%$ in HIV-positive individuals. However, this reduction is far from what is recommended in the End TB Strategy, whose targets are a 35\% reduction in tuberculosis mortality by 2020 and a
$90 \%$ reduction by $2035 .{ }^{(8)}$ This is, therefore, a bold goal that indicates the size of the challenge faced by Brazil in reaching it.

Currently, tuberculosis/HIV coinfection is one of the most important factors contributing to tuberculosis mortality worldwide. ${ }^{(8)}$ Therefore, reducing tuberculosis mortality should also involve public policies aimed at HIV detection in the population and adherence to antiretroviral therapy, given that maintaining immunological competence is essential in order not to develop tuberculosis, as well as in order to prevent death from tuberculosis. ${ }^{(5,6,9)}$

Another factor that can significantly change the trends in tuberculosis mortality in Brazil is the implementation of the "Protocolo para vigilância do óbito com menção de tuberculose nas causas de morte" (Protocol for the surveillance of deaths with any mention of tuberculosis as a listed cause of death). ${ }^{(10)}$ The purpose of this tool is to investigate deaths with any mention of tuberculosis among patients who were not reported to the Brazilian Tuberculosis Case Registry Database, reducing underreporting. ${ }^{(10)}$ Therefore, the investigation of deaths, as recommended in the protocol, may result in an increase in tuberculosis mortality and incidence rates, reflecting a more realistic epidemiological scenario.

One of the most important factors in determining the risk of tuberculosis mortality is the direct influence of treatment dropout. ${ }^{(9)}$ It is estimated that, in 2035, the tuberculosis mortality rate in Brazil will be $1.17 / 100,000$ population without there being a change in the treatment dropout rate. ${ }^{(8)}$ However, a $5 \%$ reduction in the treatment dropout rate would result in even lower mortality. Therefore, the tuberculosis mortality rate would be $0.94 / 100,000$ population rather than $1.17 / 100,000$ population, making it possible to achieve the global goal (i.e., a tuberculosis mortality rate < $1 / 100,000$ population). ${ }^{(11)}$ The adoption of measures that will result in reduced treatment dropout is a key imperative for reducing tuberculosis mortality.

In the analyses by state, our findings corroborate those of studies conducted in the states of São Paulo, ${ }^{(12)}$ Paraná,(13) and Santa Catarina. ${ }^{(14)}$ What those studies have in common is the fluctuation in mortality rates, characterized by a period of increase followed by successive periods of decline, with a stationary behavior in the last years of the time series. However, differences in rates are observed when comparing states by region. This discrepancy might reflect the influence of social inequities that act as social determinants of health and increase the risk of tuberculosis mortality. ${ }^{(15)}$ In states in the North and Northeast, where there still is persistent social vulnerability, reducing mortality becomes an even greater challenge. In addition to macro-regional social issues, there are also issues related to health care itself, such as health care coordination and epidemiological surveillance activities, resulting in difficulties in tuberculosis control by states and cities. ${ }^{(16-18)}$

Tuberculosis mortality can be influenced by the degree of integration between epidemiological surveillance 



Figure 1. Temporal evolution of mortality rate due to tuberculosis in Brazil and its regions, 1990-2015. Parameters used in the joinpoint analysis-minimum: 0; maximum: 4; selection of the model: permutation test with 4,499 replications; significance of 5\%; and error autocorrelation based on data. TB: tuberculosis; pop.: population; APC: annual percent change; and AAPC: average annual percent change. ${ }^{*} p<0.05$.

activities and the care provided, especially with regard to primary care. ${ }^{(17,18)}$ Therefore, the gap between these two components of the health care system can explain the disparities observed in state trends. In our study, the states with the highest mortality rates also showed the largest percent reductions when compared with those with the lowest rates, whose trends were stationary.

It should be noted that the present study has limitations, especially with regard to the poor quality of mortality records, including among regions. Inadequate completion of death certificates, resulting in a large number of garbage codes; difficulties in carrying out epidemiological investigations of deaths classified as having ill-defined causes; and the lack of personnel trained to perform surveillance activities are common problems found throughout Brazil, although the North and Northeast are the most affected regions. ${ }^{(19)}$ Therefore, the number of deaths may be higher than that observed, especially in those regions where health surveillance 
Table 1. Trends in the tuberculosis mortality rate (per 100,000 population) in all Brazilian states. Brazil, 1990-2015.

\begin{tabular}{|c|c|c|c|c|c|c|}
\hline \multirow[t]{2}{*}{ Region/state } & \multicolumn{3}{|c|}{ Mortality/100,000 population } & \multirow[t]{2}{*}{ Period } & \multirow[t]{2}{*}{ APC $(95 \% \mathrm{CI})$} & \multirow[t]{2}{*}{ AAPC $(95 \% \mathrm{Cl})$} \\
\hline & 1990 & 2015 & 1990 to 2015 & & & \\
\hline \multirow[t]{3}{*}{ BRAZIL } & 3.6 & 2.3 & & $1990-1998$ & $0.5(-0.3$ to 1.3$)$ & $-1.9^{*}(-2.4$ to -1.4$)$ \\
\hline & & & 3.0 & $1998-2003$ & $-5.8^{*}(-8.0$ to -3.6$)$ & \\
\hline & & & & 2003-2015 & $-1.9^{*}(-2.3$ to -1.4$)$ & \\
\hline North & 3.1 & 2.3 & 2.6 & $1990-2015$ & $-1.0^{*}(-1.3$ to -0.6$)$ & $-1.0^{*}(-1.3$ to -0.6$)$ \\
\hline RO & 4.4 & 1.4 & 2.5 & $1990-2015$ & $-4.1^{*}(-4.9$ to -3.4$)$ & $-4.1^{*}(-4.9$ to -3.4$)$ \\
\hline$A C$ & 3.7 & 2.2 & 3.6 & $1990-2015$ & $-3.7^{*}(-5.1$ to -2.3$)$ & $-3.7^{*}(-5.1$ to -2.3$)$ \\
\hline$A M$ & 3.8 & 3.3 & 3.5 & $1990-2015$ & $-0.4(-0.9$ to 0.1$)$ & $-0.4(-0.9$ to 0.1$)$ \\
\hline $\mathrm{RR}$ & 3.9 & 0.8 & 2.5 & $1990-2015$ & $-9.2^{*}(-14.4$ to -3.8$)$ & $-9.2^{*}(-14.4$ to -3.8$)$ \\
\hline \multirow[t]{2}{*}{ PA } & 3.0 & 2.6 & 2.5 & $1990-1996$ & $-6.0^{*}(-10.0$ to -1.7$)$ & $-0.6(-1.7$ to 0.5$)$ \\
\hline & & & & $1996-2015$ & $1.1^{*}(0.4$ to 1.9$)$ & \\
\hline AP & 2.5 & 1.8 & 1.9 & $1990-2015$ & $-1.8^{*}(-3.1$ to -0.4$)$ & $-1.8^{*}(-3.1$ to -0.4$)$ \\
\hline \multirow[t]{2}{*}{ TO } & 0.3 & 0.5 & 1.1 & 1990-1992 & $126.2(-25.3$ to 585.3$)$ & $4.4(-4.3$ to 13.8$)$ \\
\hline & & & & $1992-2015$ & $-2.4(-4.8$ to 0.0$)$ & \\
\hline \multirow{2}{*}{ Northeast } & 3.0 & 2.7 & 3.0 & $1990-1998$ & $1.5^{*}(0.3$ to 2.7$)$ & $-0.5^{*}(-0.9$ to -0.01$)$ \\
\hline & & & & $1998-2015$ & $-1.3^{*}(-1.7$ to -1.0$)$ & \\
\hline \multirow[t]{2}{*}{ MA } & 1.9 & 2.2 & 2.3 & $1990-2009$ & $3.1^{*}$ (1.9 to 4.4$)$ & $1.1(-0.7$ to 2.9$)$ \\
\hline & & & & 2009-2015 & $-5.1(-11.5$ to 1.8$)$ & \\
\hline \multirow[t]{3}{*}{$\mathrm{PI}$} & 2.6 & 1.4 & 2.1 & 1990-1996 & $-10.1^{*}(-17.9$ to -1.5$)$ & $-1.1(-7.4$ to 5.5$)$ \\
\hline & & & & 1996-1999 & $27.3(-25.9$ to 118.6$)$ & \\
\hline & & & & 1999-2015 & $-2.3^{*}(-4.3$ to -0.2$)$ & \\
\hline \multirow[t]{4}{*}{ CE } & 2.0 & 2.3 & 2.8 & 1990-1992 & 31.5 ( -5.8 to 83.6$)$ & $1.0(-4.7$ to 7.0$)$ \\
\hline & & & & 1992-1995 & $-13.5(-38.0$ to 20.8$)$ & \\
\hline & & & & 1995-1998 & $17.9(-15.5$ to 64.6$)$ & \\
\hline & & & & $1998-2015$ & $-2.1^{*}(-3.3$ to -1.0$)$ & \\
\hline RN & 2.0 & 1.9 & 2.2 & $1990-2015$ & $-1.0(-2.2$ to 0.3$)$ & $-1.0(-2.2$ to 0.3$)$ \\
\hline PB & 1.7 & 2.2 & 2.0 & $1990-2015$ & $1.1(-0.2$ to 2.5$)$ & $1.1(-0.2$ to 2.5$)$ \\
\hline \multirow[t]{3}{*}{ PE } & 4.8 & 4.5 & 5.0 & $1990-1998$ & $2.6^{*}(0.7$ to 4.4$)$ & $-0.3(-1.7$ to 1.1$)$ \\
\hline & & & & $1998-2013$ & $-3.0^{*}(-3.7$ to -2.2$)$ & \\
\hline & & & & 2013-2015 & $9.1(-7.4$ to 28.6$)$ & \\
\hline $\mathrm{AL}$ & 2.5 & 2.3 & 2.7 & $1990-2015$ & $1.0^{*}(0.2$ to 1.8$)$ & $1.0^{*}(0.2$ to 1.8$)$ \\
\hline SE & 2.3 & 2.0 & 2.0 & $1990-2015$ & $0.0(-0.8$ to 0.9$)$ & $0.0(-0.8$ to 0.9$)$ \\
\hline BA & 3.8 & 2.7 & 3.2 & $1990-2015$ & $-1.6^{*}(-1.9--1.2)$ & $-1.6^{*}(-1.9$ to -1.2$)$ \\
\hline \multirow[t]{3}{*}{ Southeast } & 4.6 & 2.4 & 3.5 & $1990-1997$ & $1.0(-0.0$ to 2.1$)$ & $-2.7^{*}(-3.1$ to -2.2$)$ \\
\hline & & & & $1997-2005$ & $-6.9^{*}(-7.9$ to -5.9$)$ & \\
\hline & & & & $2005-2015$ & $-1.7^{*}(-2.3$ to -1.1$)$ & \\
\hline \multirow[t]{2}{*}{ MG } & 2.4 & 1.1 & 1.8 & $1990-2011$ & $-2.5^{*}(-3.0$ to -2.1$)$ & $-3.3^{*}(-4.2$ to -2.4$)$ \\
\hline & & & & 2011-2015 & $-7.2^{*}(-12.3$ to -1.8$)$ & \\
\hline \multirow[t]{3}{*}{ ES } & 2.3 & 1.9 & 2.4 & $1990-1993$ & $11.1(-2.9$ to 27.1$)$ & $-0.9(-2.7$ to 1.0$)$ \\
\hline & & & & $1993-2005$ & $-5.3^{*}(-7.0$ to -3.6$)$ & \\
\hline & & & & $2005-2015$ & $1.1(-1.0$ to 3.3$)$ & \\
\hline \multirow[t]{3}{*}{ RJ } & 9.1 & 5.0 & 7.0 & $1990-1995$ & $3.2(-0.01$ to 6.5$)$ & $-2.1^{*}(-2.9$ to -1.3$)$ \\
\hline & & & & $1995-2005$ & $-6.1^{*}(-7.3$ to -4.9$)$ & \\
\hline & & & & $2005-2015$ & $-0.6(-1.7$ to 0.5$)$ & \\
\hline \multirow[t]{3}{*}{ SP } & 4.1 & 2.0 & 3.2 & 1990-1999 & $0.8(-0.1$ to 1.7$)$ & $-3.0^{*}(-3.6$ to -2.4$)$ \\
\hline & & & & 1999-2005 & $-10.3^{*}(-12.2$ to -8.3$)$ & \\
\hline & & & & $2005-2015$ & $-1.8^{*}(-2.6$ to -1.1$)$ & \\
\hline \multirow[t]{3}{*}{ South } & 2.5 & 1.6 & 2.2 & 1990-1994 & $4.8(-0.6$ to 10.5$)$ & $-1.8^{*}(-3.3$ to -0.3$)$ \\
\hline & & & & $1994-2013$ & $-4.0^{*}(-4.6$ to -3.5$)$ & \\
\hline & & & & 2013-2015 & $7.7(-8.9$ to 27.4$)$ & \\
\hline
\end{tabular}

APC: annual percent change; AAPC: average annual percent change; RO: Rondônia; AC: Acre; AM: Amazonas; RR: Roraima; PA: Pará; AP: Amapá; TO: Tocantins; MA: Maranhão; PI: Piauí; CE: Ceará; RN: Rio Grande do Norte; PB: Paraíba; PE: Pernambuco; AL: Alagoas; SE: Sergipe; BA: Bahia; MG: Minas Gerais; ES: Espírito Santo; RJ: Rio de Janeiro; SP: São Paulo; PR: Paraná; SC: Santa Catarina; RS: Rio Grande do Sul; MS: Mato Grosso do Sul; MT: Mato Grosso; GO: Goiás; and DF: Distrito Federal (Federal District of Brasília).*p $<0.05$. 
Table 1. Continued...

\begin{tabular}{|c|c|c|c|c|c|c|}
\hline \multirow[t]{2}{*}{ Region/state } & \multicolumn{3}{|c|}{ Mortality/100,000 population } & \multirow[t]{2}{*}{ Period } & \multirow[t]{2}{*}{ APC $(95 \% \mathrm{CI})$} & \multirow[t]{2}{*}{ AAPC (95\% CI) } \\
\hline & 1990 & 2015 & 1990 to 2015 & & & \\
\hline \multirow[t]{3}{*}{ PR } & 2.0 & 1.1 & 1.9 & 1990-1998 & $3.8^{*}(0.9$ to 6.7$)$ & $-2.5^{*}(-4.2$ to -0.7$)$ \\
\hline & & & & $1998-2012$ & $-7.0^{*}(-8.3$ to -5.8$)$ & \\
\hline & & & & $2012-2015$ & $3.6(-8.9$ to 17.9$)$ & \\
\hline SC & 1.1 & 0.8 & 1.1 & $1990-2015$ & $-2.1^{*}(-2.8$ to -1.3$)$ & $-2.1^{*}(-2.8$ to -1.3$)$ \\
\hline \multirow[t]{5}{*}{ RS } & 3.6 & 2.6 & 3.0 & $1990-1993$ & $4.8(-3.1$ to 13.3$)$ & $-1.3(-3.7$ to 1.2$)$ \\
\hline & & & & $1993-2006$ & $-4.1^{*}(-5.0$ to -3.2$)$ & \\
\hline & & & & 2006-2009 & $2.7(-12.2$ to 20.2$)$ & \\
\hline & & & & $2009-2013$ & $-6.4(-13.4$ to 1.3$)$ & \\
\hline & & & & 2013-2015 & $13.9(-2.6$ to 33.2$)$ & \\
\hline \multirow[t]{2}{*}{ Central-West } & 1.6 & 1.4 & 1.8 & $1990-1998$ & $2.7^{*}(0.2$ to 5.2$)$ & $-1.3^{*}(-2.2$ to -0.4$)$ \\
\hline & & & & $1998-2015$ & $-3.1^{*}(-3.9$ to -2.4$)$ & \\
\hline MS & 2.4 & 1.8 & 2.8 & $1990-2015$ & $-1.3^{*}(-2.2$ to -0.3$)$ & $-1.3^{*}(-2.2$ to -0.3$)$ \\
\hline \multirow[t]{2}{*}{ MT } & 2.2 & 2.2 & 3.0 & $1990-1998$ & $7.0^{*}(2.7$ to 11.4$)$ & $-0.4(-1.9$ to 1.0$)$ \\
\hline & & & & $1998-2015$ & $-3.8^{*}(-5.0$ to -2.5$)$ & \\
\hline \multirow[t]{2}{*}{ GO } & 0.9 & 1.1 & 1.2 & $1990-1993$ & $16.9(-2.3$ to 39.8$)$ & $0.1(-2.0$ to 2.3$)$ \\
\hline & & & & $1993-2015$ & $-2.0^{*}(-2.8$ to -1.1$)$ & \\
\hline DF & 1.9 & 0.5 & 1.0 & $1990-2015$ & $-5.9^{*}(-7.5$ to -4.3$)$ & $-5.9^{*}(-7.5$ to -4.3$)$ \\
\hline
\end{tabular}

APC: annual percent change; AAPC: average annual percent change; RO: Rondônia; AC: Acre; AM: Amazonas; RR: Roraima; PA: Pará; AP: Amapá; TO: Tocantins; MA: Maranhão; PI: Piauí; CE: Ceará; RN: Rio Grande do Norte; PB: Paraíba; PE: Pernambuco; AL: Alagoas; SE: Sergipe; BA: Bahia; MG: Minas Gerais; ES: Espírito Santo; RJ: Rio de Janeiro; SP: São Paulo; PR: Paraná; SC: Santa Catarina; RS: Rio Grande do Sul; MS: Mato Grosso do Sul; MT: Mato Grosso; GO: Goiás; and DF: Distrito Federal (Federal District of Brasília).*p $<0.05$.

faces operational problems due particularly to the lack of (human, financial, and material) resources. ${ }^{(19)}$

Although many advances have been observed in tuberculosis control in recent years, ${ }^{(20)}$ the temporal behavior of tuberculosis mortality rates that was observed during the period in question and the gap among states confirms that tuberculosis continues to be a major public health problem in Brazil. Therefore, regional and local strategies that can reduce tuberculosis mortality are needed. We advocate that, in order to reduce the problem, broad strategies of intervention, focused particularly on the social determinants of health, are needed.

\section{REFERENCES}

Houben RM, Dodd PJ. The Global Burden of Latent Tuberculosis Infection: A Re-estimation Using Mathematical Modelling. Plos Med. 2016;13(10):e1002152. http://dx.doi.org/10.1371/journal. pmed. 1002152

2. World Health Organization [homepage on the Internet]. Geneva: World Health Organization [cited 2018 Dec 2]. Global tuberculosis report 2018. [Adobe Acrobat document, 265p.]. Available from: http:// apps.who.int/iris/bitstream/handle/10665/274453/9789241565646eng.pdf?ua=1

3. Brasil. Ministério da Saúde. Secretaria de Vigilância em Saúde [homepage on the Internet]. Brasília: o Ministério. c2018; [cited 2018 Dec 2]. Série histórica do número de casos novos de tuberculose. Brasil, Regiões e Unidades Federadas de residência por ano diagnóstico (1990 a 2017). [Adobe Acrobat document, 1p.]. Available from: http://portalarquivos2.saude.gov.br/images/pdf/2018/ marco/19/Casos-novos-tuberculose-1990-2017-base-JAN-2018.pdf

4. 4-Brasil. Ministério da Saúde. Secretaria de Vigilância em Saúde [homepage on the Internet]. Brasília: o Ministério. c2018; [cited 2018 Dec 2]. Série histórica do coeficiente de incidência de tuberculose. Brasil, Regiões e Unidades Federadas de residência por ano de diagnóstico (1990 a 2017). [Adobe Acrobat document, 1p.]. Available from: http://portalarquivos2.saude.gov.br/images/pdf/2018/ marco/19/taxa-incidencia-tuberculose-1990-2017-JAN-2018.pdf

5. World Health Organization [homepage on the Internet]. Geneva: World Health Organization, c2015; [cited 2018 Dec 2].Global tuberculosis report 2015. [Adobe Acrobat document, 1p.]. Available from: http:// apps.who.int/iris/bitstream/handle/10665/191102/9789241565059_ eng.pdf? sequence $=1$

6. Brasil. Ministério da Saúde [homepage on the Internet]. Brasilia: Ministério da saúde [cited 2018 Dec 2]. Brasil livre da tuberculose.
Plano nacional pelo fim da tuberculose como problema de saúde pública. 1st ed; 2017 [Adobe Acrobat document, 40p.]. 2017. Available from: http://portalarquivos.saude.gov.br/images/pdf/2017/ fevereiro/24/Plano-Nacional-Tuberculose.pdf

7. Kim HJ, Fay MP, Feuer EJ, Midthune DN. Permutation tests for joinpoint regression with applications to cancer rates. Stat Med. 2000;19(3):335- 51

8. World Health Organization [homepage on the Internet]. Geneva: World Health Organization [cited 2018 Dec 2] Implementing the End TB Strategy: the essentials. [Adobe Acrobat document, 1p.]. Available from: http://apps.who.int/iris/bitstream/ handle/10665/191102/9789241565059_eng.pdf?sequence=1

9. Pereira AGL, Escosteguy CC, Gonçalves JB, Marques MRVE, Brasi CM, Silva MCS. Fatores associados ao óbito e ao abandono do tratamento da tuberculose em um hospital geral do município do Rio de Janeiro, 2007 a 2014. Rev Epidemiol Control Infec. 2018;8(2):150158. http://dx.doi.org/10.17058/reci.v8i2.10675

10. Brasil. Ministério da Saúde [homepage on the Internet]. Brasilia: Ministério da saúde. c2017; [cited 2019 Jan 27]. Protocolo de vigilância do óbito com menção de tuberculose nas causas de morte. [Adobe Acrobat document, 68p.]. Available from: http:// portalarquivos2.saude.gov.br/images/pdf/2017/julho/12/capa_ protocolo_TB_final.pdf

11. Brasil. Ministério da Saúde [homepage on the Internet]. Brasilia: Ministério da Saúde. c2016; [cited 2018 Dec 2]. Boletim Epidemiológico de Tuberculose. 2016 [Adobe Acrobat document, 15p.]. Available from: http://portalarquivos2.saude.gov.br/images/ pdf/2016/marco/24/2016-009-Tuberculose-001.pdf

12. Feitoza DS, Clares JWB, Rodrigues LV, Almeida PC. Vigilância epidemiológica no contexto do programa de controle da tuberculose: 
limites e possibilidades. Rev Rene. 2012;13(5):1066-1074.

13. Cecilio HPM, Santos AL, Marcon SS, Latorre MDRDO, Mathias TAF Rossi RM. Tuberculosis mortality trend in the state of Paraná, Brazi - 1998-2012. Cienc Saude Coletiva. 2018:23(1):241-248. http://dx. doi. org/10.1590/1413-81232018231.25242015

14. Traebert J, Ferrer GC, Nazário NO, Schneider IJ, Silva RM Temporal trends in tuberculosis-related morbidity and mortality in the state of Santa Catarina, Brazil, between 2002 and 2009. J Bras Pneumol. 2012;38(6):771-5. http://dx.doi.org/10.1590/S180637132012000600014

15. Munayco CV, Mújica OJ, León FX, del Granado M, Espinal MA Social determinants and inequalities in tuberculosis incidence in Latin America and the Caribbean. Rev Panam Salud Publica. 2015;38(3):177-85

16. Mello FCQ, Silva DR, Dalcolmo MP. Tuberculosis: where are we? J Bras Pneumol. 2018;44(2):82. http://dx.doi.org/10.1590/s180637562017000000450
17. Sousa MGG, Andrade JRS, Dantas, CF, Cardoso MD. Investigação de óbitos por tuberculose, ocorridos na Região Metropolitana do Recife (PE), registrados no Sistema de Informação de Mortalidade, entre 2001 e 2008. Cad Saude Colet. 2012;20(2):153-60.

18. Theme Filha MM, Daumas RP, Alves LC, Leimann BCQ, Engstrom EM. Análise da tuberculose em uma unidade de Atenção Primária a Saúde na cidade do Rio de Janeiro: perfil clínico, resultado de tratamento e qualidade dos registros. Cad Saude Colet. 2012;20(2):169-76

19. Ishitanil LH, Teixeira RA, Abreu $D M X$, Paixão LMMM, França EB. Quality of mortality statistics' information: garbage codes as causesof death in Belo Horizonte, 2011-2013. Rev Bras Epidemiol. 2017;20(Suppl 1):34-45. http://dx.doi.org/10.1590/19805497201700050004

20. Duarte R, Silva DR, Rendon A, Alves TG, Rabahi MF, Centis R, et al. Eliminating tuberculosis in Latin America: making it the point. Bras Pneumol. 2018;44(2):73-76. http://dx.doi.org/10.1590/S180637562017000000449 